\title{
CRITICAL THINKING FOR QUALITY EDUCATION
}

\author{
Bhawani Prasad Mainali \\ Department of EPM
}

\begin{abstract}
Critical thinking is a recent educational paradigm. It is a powerful thinking skill that empowers learners and facilitates creative and qualitative teachinglearning process. This article deals with the concept of critical thinking for quality education. Morever, it also identifies the rationale of critical thinking and its implications in Nepalese education .
\end{abstract}

\section{Keywords}

Critical thinking, creativity, concretization, culture of silence, quality education.

\section{Introduction}

Confucius maintained that learning without thinking is useless. This infers the significance of critical thinking (CT) in teaching learning activities .Today many teachers and educationists realize that engaged teaching and active learning are desirable. Teaching that encourages students to ask questions and look for answers, to apply what they have learned in order to solve problems ,to listen to each other and debate ideas politely and constructively, is said to have the characteristics of critical thinking approach to teaching and learning . The teachers who want to change their teaching practices encourage their students not just to memorize, but to question, examine, create, solve, interpret and debate the material in their courses. Such teaching - learning is now widely recognized as 'best practice'. Studies (Gardner, 1993; Marzano, 2001) show that active classes, so long as they are purposeful and well organized are often the ones in which students learn the material most fully and usefully. Learning fully and usefully means that students can think about what they learn, apply it in real situations or toward further learning and can continue to learn independently (cited in Crawford et al., 2005, p.1).

CT is an approach to thinking that emphasizes stating original claims or opinions and supporting them with reasons. The most successful classrooms are those that encourage students to think for themselves and engage in critical thinking (ibid.). CT allows us to think about our own thoughts and the reasons 
behind our points of view. It means that we reflect on our own ways of making decisions or solving problems. Thinking like this means that our thoughts are consciously directed to some goals .Our thoughts and ideas are based not on our biases or prejudices but on logic and information we might gather and filter from many sources. As we think critically, we are always mindful of what and how we are thinking. The students who think critically are excited about their learning. They see challenges and opportunities for learning in even the most difficult intellectual tasks. These students are mindful of opportunities to use their critical thinking skills typically engage these opportunities eagerly whether in the classroom or in the world of their own communities .These are the students who make teaching - learning enjoyable and exciting.

\section{Concept of CT}

Thinking is conscious purposeful mental activity and critical thinking refers to the processes and methodologies that employ reason, insight, awareness, imagination and sensibility in order to criticize and evaluate a text, an object or a thing. Usually, the use of the phrase 'critical' is taken negatively and is generally associated with fault finding. However, critical also means involving or exercising skilled judgment or observation. In this sense, critical thinking (CT) means thinking clearly and intellectually. Here its core idea is not negative but a procedure for analyzing knowledge and then evaluating it. Moreover, critical means a standard for judging. Critical thinking is a purposeful form of mental activity. CT is evaluative or reflective consideration about the validity. It is a type of thinking needed to scrutinize, analyze and criticize. It may involve the application and comparison of fixed or developed criteria. It is a professional development program for educators that introduces research based, instructional methods to help students think reflectively, take ownership of their personal learning, understand the logic of arguments, listen attentively, debate confidently and become independent and lifelong learners. It is used respectively when students critique other people's arguments. It is a well organized strategy for teaching that invites and supports learning. It can be used for all subjects and all levels with existing curricula. In this approach students learn by exploring and inquiring freely and logically.

CT employs not only logic but broad intellectual criteria such as clarity, credibility, accuracy, precision, relevance, depth, breadth, significance and fairness. It means changed way of observation, thinking, feeling and doing things through the process of inquiry and exploration. Thus, CT is disciplined thinking, correct thinking, self guided thinking, own thinking, structure and independent thinking, reflective and real thinking, logical and positive thinking. All education consists of transmitting to students two different things: the subject matter -'what to think' and the correct way to understand and evaluate this subject matter- 'how to think'. We do an excellent job of transmitting the content but we often fail to teach students how to think effectively about this subject matter and how to properly understand and evaluate it. The second ability is CT. Putting all this information together, we can define critical thinking as consciously observing, analyzing, reasoning and evaluation according to proven standards.

\section{Rationales behind critical thinking}

The new century is bringing in a new socioeconomic scenario with liberalization and globalization of the economy. In such an open situation, we are facing a severe competition, where only the fittest will grow. Is our society and education ready for such a change? How do we prepare our people and students for such a competitive environment? In this context, we should give greater emphasis on quality parameters. Hence, CT is going to play key role in the knowledge and skill based society. In the new socio-economic 


\section{B. Mainali}

order, quality, creativity and management are going to play a major role, which are related to CT. The development of a society and education depends on the creativity and CT of the people and students. Creativity and CT enhance capacity to make changes in the surroundings. It is also seen that CT and creativity adds meaning to our life. We are able to enjoy more, when we are involved in it. The total change in the society and education depends on the creative and critical capacity of its real stakeholders to effects such a change. Since learner is an active participant in the process, he/she tries to add new flavor to whatever s/he receives from the teacher. In this Process, a learner is able to realize his/her maximum productive potential, and it leads to self-actualization. Critical learning ensures proper understanding of the matter.

Freire(1970) believed in liberating power of education which is possible provided it avoids authoritarian teacher- pupil models and is based on the actual experiences of students and continual shared investigation. Such a dialogue, Freire argues, develops the ability for creative, critical intelligence rather than passive reception of information, avoids the danger of formerly uneducated people using their education to become a new type of oppressor, and is the only way to break the culture of silence. In his opinion, education is suffering from narration sickness. The outstanding characteristic of this narrative education, then, is the sonority of words, not their transforming power. Education thus becomes an act of depositing, in which the students are the depositories and the teacher is the depositor. Instead of communicating, the teacher issues communiqués and make deposit which the students patiently receive, memorize and repeat. This is the banking concept of education, in which the scope of action allowed to the students extends only as far as receiving, filing and storing the deposits. Education should be based on conscientization of the situation. Conscientization depends on the attitude of awareness characteristic of all emergence and critical thinking opportunity.Critical thinking rejects the banking concept of education. CT becomes the practice of freedom, the means by which students deal critically and creatively with reality and discovers how to participate in the transformation of their world.

What is important is learning, not teaching. Teaching effectiveness depends not just on what the teacher does, but rather on what the student does. Teaching involves listening as much as talking. It is important that both teacher and students are actively thinking, but most important is what goes on in the students' mind. Those minds are not blank slates. They hold expectations, experiences and conceptions that will shape their interpretation of the knowledge and subject matter (Makeachie, 2006). Cooperative groups and peer learning are valuable tools for effective teaching. Similarly, content centered teachers share important facts and concepts with student and show limited attention to the process. In contrast, learner centered teachers accept the responsibility for promoting changes in students' thinking skills. Thus, CT is important for quality education.

Critical thinking provides opportunity for intellectual autonomous and freedom. Self assessment has assumed prominence in education circles as an effective means of helping students develop a myriad of qualities. These include improved self esteem, enriched self concept, self empowerment, autonomy, higher achievement, persistence, more indepth understanding etc. (Boud, 1986 \& Sadler, 1989, cited in McDonald, 2008, p.38).

When we change ourselves, the world changes with us, both in the way that the world is affected by our changed actions and in the changed way that we experience the world. It is expected that increasing our creativity and critical thinking will help us, our organization and our clients become happier through improvements in our quality and quantity of output (Sinha, 2008). All these information and activities are related to $\mathrm{CT}$, which can 
help to develop quality of education.

CT plays a vital role in promoting democratic values. In $\mathrm{CT}$, we can think freely and variations and keep session relaxed and playful. The rationale of specifically teaching critical thinking in any discipline is to improve the thinking skills of students and thus better prepare them to succeed in the world. Thus, all teachers and educators are interested in teaching critical thinking to their students.

\section{Critical thinking and quality education}

Quality is a relative term and is much debated and talked about but is a little understood phenomenon. Uniformity in quality and strategic approaches to its sustainability are the widespread issues that may differ from country to country. Quality of education is determined by the development of total personality of the students. It is that which related to the emerging needs of the society and learners and is guided by people's expectations. Therefore, it is need based education which is referred to as quality education. It should be relevant and compatible with people's life and livelihood. Meeting minimum enabling conditions in all schools is the pre-requisite to the quality. The SSR plan intends to make sure that all schools are equipped with minimum enabling conditions that cater to the diverse needs (SSR Plan, 2009).

Education should aim at supporting the development of independent thinkers who are discerning problem solvers. Any discussion of quality education usually concentrates on some issues such as student level of achievement, relevance for lifeafterschool, and conditions of learning (teachers, facilities and instructional material). In order to maintain quality in education, it is necessary that there is quality in content and methods of teaching, management of educational process, what the students learn, and how to adapt education to changing needs through innovation (Coombs, 1968, cited in Ranjit, 2004, p.101). In inclusive viewpoint, quality education today has been defined from several perspectives: access, equity, equality, full participation, inclusion, integration and empowerment. Satisfaction replaced excellence to denote quality since the beginning of $21^{\text {st }}$ century. Similarly, diversity management has found a way into the arena of quality education today. Being responsive to diversities and sensitive to the principles of inclusion, quality education has become an overriding concern of stakeholders (Kafle, 2010).

Quality is customer- driven and market focused (Arcaro, 1997, p.5). Nowadays, education is being seen as an empowerment process. The ultimate objective of the education system should be to empower people (students) to fructify their own inherent potential (Prakash, 2010, p.137). In the context of quality education, we should also analyze the four pillars of learning expounded in Delors's report, 1996 (cited in Prakash , 2010, p.204). They are:

Learning to know: Learning to know creatively, in fact, is learning to master the art of learning. This model of learning, leads us to organize new learning occasion, which in turn stimulate learners to learn techniques of self learning. Self learning empowers a person to learn at all occasions and at all times.

Learning to do: Learning to do creatively and critically refers to the ability or competency of learning to apply knowledge. Knowledge can be useful only if it is properly applied in life situation. So, creative and critical learning methodology must empower learners in developing competence in doing creative things.

Learning to live together: One of the serious defects of the present education system is that it promotes individualism. Each learner is considered as separate entity as if he/she has nothing in common with others. But in actual life situation, work is seldom done individually. With increasing sophistication 


\section{B. Mainali}

in almost all walks of life, people have to face more and more complexities. Such complexities can be better handled by groups than by individuals. So, education should develop group co-operative skills.

Learning to be: We have seen that each child has a unique learning style and thus the learning strategies for each child are unique. One should not try to follow a rigid pattern for teaching all children, nor should one try to imitate others. Each child is unique both in terms of learning style as well as learning potential. Hence, there is need to design learning environment, learning activities, teaching learning tools and aids to suit one's learning style and potential. Therefore, the major emphasis of activities at schools should change from teaching to learning. We should try and help a child realize its own inherent potential rather than imitate others. CT is said to promote the four pillars of learning.

\section{ABC format of CT approach}

The $\mathrm{ABC}$ format for planning a lesson in $\mathrm{CT}$ consists of three phases which are elaborated below:

Anticipation phase : Each lesson begins with a phase of anticipation, in which students are directed to think and ask questions about the topics they are about to study. The anticipation phase serves to call up the knowledge students already have; informally assess what they already know, including misconception; set purposes for learning; focus attention on the topic and provide a context for understanding new idea.

Building knowledge phase: After the lesson gets started, the teaching leads students to inquire, find out , make sense of the material , answer their prior questions, and find new questions and answers. We call this second phase of the lesson the building knowledge phase. The building knowledge phase serves to compare expectations with what is being learned; revise expectations or raise new ones; identify the main points; monitor personal thinking; make inferences about the material; make personal connections to the lesson and question the lesson.

Consolidation phase : Toward the end of the lesson, teachers want students to reflect on what they learned, ask what it means to them, reflect on how it changes what they thought, and ponder how they can use it. This phase of the lesson is called the consolidation phase which serves to summarize the main ideas; interpret the ideas; share opinions; make personal responses; test out the ideas; assess learning and ask additional questions.

$\mathrm{CT}$ is pervasive and essential in teaching and learning process. CT has many teaching learning strategies for the thinking classroom. In the informational type of text (Topic), we can use structure overview or think/pair/ share $(\mathrm{T} / \mathrm{P} / \mathrm{S})$ strategy for anticipation phase. Paired reading / paired summarizing can be used for building knowledge phase and quick write or value line for consolidation phase. What? So what? Now what? Or K-W-L chart is also appropriate for this type of text. Similarly, in large size of classes and cooperative type of learning context, we can use Mix/Freeze/Pair strategy for phase A, Reading with text coding strategy for phase B, and Jigsaw strategy for phase $C$. The proper selection and use of teaching learning strategies enhance quality of teaching learning process. CT strategies invite students to learn actively and think critically. CT methods are adapted for classrooms in order to promote the active inquiry, student initiated learning, active listening, problems solving, cooperative learning, accept diverse ideas and opinions, give permission for students to speculate etc.

\section{CT in Nepalese education?}

There have been grievances amongst many that the existing teaching learning situation of Nepal is not that useful and life oriented. Nepal's schools rarely encourage creativity and critical thinking opportunity. To improve the nation's education system, we need to revamp 
the teacher-student relationship and teaching learning processes. Child centered and child friendly learning is today's need for quality education. At the same time supporting students in developing critical thinking is of utmost importance. Unfortunately the current teaching approach and methodology is not really going in that direction. We are engaged in only transmitting or vomiting information. The teaching and learning situation is thus demotivating. There is an urgent need for change in the existing teaching learning process in order to maintain quality education. The situation is demanding us to implement the four pillars of education in our teaching learning process which covers diverse situation.

In Nepalese education, CT is virtually a new concept. Therefore, it is necessary that stakeholders of education are made aware of CT concept. Similarly, it is important that teachers are trained on critical thinking. Then trained teachers can use CT concepts and its teaching learning strategies in their classrooms. Teachers can also use the elements (observations, facts, inferences, assumptions, opinions, arguments, and critical analysis) of CT in teaching learning situation which provides broad base of learning. CT supports post method pedagogical concept, such as particularity, practicality and possibility which is the call of time.

\section{Conclusion}

CT is beneficial for many reasons. It can help students to better in schools and colleges by improving their understanding. It helps people succeed in their career by improving their ability to solve the problems, think creatively and communicate their ideas clearly and effectively.

Society demands the quality of education but not success. Educational professional must be aware of the fact that the commercial quality program will not work in education. The quality of education will improve when stakeholders develop new attitudes and CT skill. Education has to be designed in such a way that the inherent potential of all students should fully blossom through the process of teaching learning activities.

The education system of Nepal needs to promote the values of democracy and open society by developing students as critical thinkers, skilled workers and active and thinking citizens. The education system that we have now is not suitable for critical teaching learning and does not guarantee autonomous and self motivated learners so urgently required for federal democratic Nepal.

\section{References}

Arcaro, J.S. (1997). Quality in education. New Delhi: Vanity Books International.

Crawford, A, Saul, E.W. Mathews, s. \& Makinster, J. (2005). Teaching and learning strategies for the thinking classroom. Kathmandu: ASD.

Freire, P. (1970). Pedagogy of the oppressed. New York: Continuum.

Jnawali, D. (2007). Making trends of social studies in SLC examination. Journal of TESON, 1,35.

Kafle, B.D. (2010). Quality education: inclusive perspective. Journal of EPMAN,2,1-5.

Lohani, S., Adhikari, R., Subedi, A., \& Gupto, A. (Eds.). (2008). Critical andCreative thinking. Kathmandu: Educational Publishing House.

Mainali, B.P. (2011) . A comparative study on traditional and critical thinking teachinglearning. Unpublished, Goreto Nepal, Lalitpur.

Makeachie, W.J. \& Svonicki,M. (2006 Teaching tips. New york: Houghton Miffilin Company. 


\section{B. Mainali}

McDonald, B.(2008). Enhancing thinking through self assessment. Thinking classroom, 9,38.

MCGregor, D. (2010). Developing thinking, developing learning. New Delhi: Tata MCGraw Hill.

Ministry of Education (2009). School sector reform plan.Kathmandu: Author.

Prakash, V. (2010). Creative learning. New Delhi: Viva Books.

Ranjit, K. (2007). Contemporary issuss on population and quality education in Nepal. Teacher Education, 5, 100-101.

Sinha, R. (2007). Creative thinking and its implication to education/traning. Teacher Education, 5, 178-180.

Schafersman, S.D. (1991). An introduction to critical thinking. New Delhi:Tata McGraw-Hill.

Sharma, J.P. (2010). Critical thinking approach: A revolution in teaching learning strategy. ILAM,8, 4-7.

\section{The Author}

Bhawani Prasad Mainali has been teaching various courses on Educational Planning and Management in Thakur Ram Multiple Campus, Birgunj for the last seven years. He has attended 25 day long Critical Thinking Training organized by Alliance for Social Dialogue, Nepal. He has also carried out mini-researches entitled "Expected and Performed Role and Function of Head Teachers" offered by Dean Office, Faculty of Education, TU. and "A comparative study on traditional and critical thinking teaching learning offered by Goreto Nepal.

Email: bhawanimainali@gmail.com 